\title{
INFRADIAPHRAGMAL RADIOTHERAPY IN PATIENTS WITH LYMPHOMA: VOLUME DEFINITION AND SIDE EFFECTS
}

\author{
Lea Galunić Bilić ${ }^{1}$ and Fedor Šantek ${ }^{1,2}$ \\ ${ }^{1}$ Department of Oncology and Radiotherapy, Zagreb University Hospital Centre, Zagreb, Croatia; \\ ${ }^{2}$ University of Zagreb, School of Medicine, Zagreb, Croatia
}

\begin{abstract}
SUMMARY - Lymphomas are very radiosensitive and radiotherapy (RT) was the first treatment modality that enabled cure. It is the most effective single modality for local control of lymphomas. However, as a local form of treatment, curative intention is only possible if all lymphoma tissue can be incorporated in the volume to be irradiated with the prescribed total irradiation dose. That is why RT is a single modality only in early stage of nodular lymphocyte predominance Hodgkin's lymphoma and low grade non-Hodgkin's lymphoma. In most patients, RT can be used as consolidation therapy after chemotherapy or as salvage after failure of chemotherapy. In the past two decades, irradiation techniques have been improved in order to spare critical tissues and reduce toxicity. Although effective, $\mathrm{RT}$ is a neglected modality of treatment because of the appearance of new drugs and fear of side effects after irradiation. Radiation has been shown to be effective in the treatment of all stages and forms of lymphoma. Study data are still mostly derived from patients that received supradiaphragmal RT; therefore, there is no agreement about the best management approach in patients with infradiaphragmal lymphoma.
\end{abstract}

Key words: Lymphoma, non-Hodgkin; Radiation tolerance; Radiotherapy

\section{Introduction}

Lymphomas are very radiosensitive and radiotherapy (RT) was the first treatment modality that enabled cure. It is the most effective single modality for local control of lymphomas and an important part of the treatment for many patients. However, as a local form of treatment, curative intention is only possible if all lymphoma tissue can be incorporated into the volume that is irradiated with the total irradiation dose prescribed. Today, RT as a single modality is used as the primary treatment in early stage of nodular lymphocyte predominance of Hodgkin's lymphoma and in early stage of indolent non-Hodgkin's lymphoma

Correspondence to: Lea Galunić Bilić, MD, Zagreb University Hospital Centre, Department of Oncology, Kišpatićeva 12, HR-10000

Zagreb, Croatia

E-mail: lgbilic@gmail.com

Received July 11, 2018, accepted August 27, 2018
(NHL). In most patients, RT is part of combined treatment modalities as consolidation after chemotherapy. In patients with advanced stages of the disease, RT can be used as part of the planned treatment when RT is applied to high-risk recurrence sites and in cases of insufficient response to chemotherapy ${ }^{1-5}$.

Radiation has been shown to be effective in the treatment of all stages and forms of lymphoma, but there is no consensus on the size of the field or the dose administered in the abdominal area. All current knowledge, radiation guidelines, and radiation side effects are retrieved for supradiaphragmal fields. Treatment of lymphoma in the abdominal area is the issue of existing controversy. Although effective, RT is a neglected form of treatment due to the appearance of new drugs and because of the fear of side effects after irradiation. In addition, there is no consensus about the use of RT as consolidation therapy after remission on chemotherapy or salvage RT when chemotherapy is unsuccessful. 


\section{Radiotherapy in the Treatment of Lymphomas}

Since the discovery of x-rays, RT has played an important role in the treatment of lymphomas. At the beginning, RT was limited to temporary control and palliation. In the 1960s, RT was an almost exclusive modality in offering a curative approach to early stage aggressive lymphomas, ${ }^{6,7}$. In stage I of the disease, treatment modality that included Involved Field (IFRT) or Extended Field (EFRT) radiotherapy provided approximately 50\% cure rate. In stage II NHL, RT alone could not achieve cure. In stage II patients, survival was only $20 \%$. Due to the systemic nature of many types of NHL and the introduction of highly effective chemotherapy protocols, $\mathrm{RT}$ was neglected as a treatment option in NHL patients. In the 1990s, RT had a great return in the treatment of both aggressive and indolent $\mathrm{NHL}^{8,9}$.

Most relapses in patients treated only with RT were either extra nodal or out-of-field. The advent of effective chemotherapy protocols for aggressive NHL has led to practical abandoning RT from the treatment of patients in early NHL stages. Several randomized studies showed that adjuvant chemotherapy followed by radiation resulted in significantly better survival without relapse than just RT in early stages. In some studies, better survival without relapse resulted in better overall survival ${ }^{10-14}$.

Adjuvant RT has become the standard of treatment in early stages of aggressive NHL. This analysis is based on the two large randomized studies conducted by the Eastern Cooperative Oncology Group (ECOG) and Southwest Oncology Group (SWOG). They demonstrated the superiority of the combined modality treatment versus chemotherapy alone in stage I and II high-grade lymphoma. Both studies confirmed the importance of adjuvant RT for primary involvement of the disease in patients that achieved complete remission after a short (3-cycle) or long (8-cycle) chemotherapy protocol. Relatively low radiation doses of 30 Gy were sufficient for patients with complete remission in the ECOG study. Higher radiation doses (40-55 Gy) were applied in the SWOG study $^{15,16}$.

Poor results achieved by radiation alone and the occurrence of relapse outside the radiation field in early stage NHL have demonstrated the systemic nature of aggressive lymphoma and stressed the importance of using chemotherapy in these situations. On the other hand, ECOG and SWOG studies emphasize that local therapy is an important component in the treatment, even in achieving complete remission in diseases that are primarily systemic ${ }^{15,16}$.

The role of RT in advanced stage aggressive NHL is still controversial. Some centers rarely recommend the use of adjuvant radiotherapy in patients with stage III and IV NHL, even in cases of bulky disease or partial response to chemotherapy.

The standard treatment of patients in advanced stages of (III and IV) of aggressive NHL is a combination of chemotherapy. The most effective and commonly used is the R-CHOP (rituximab and cyclophosphamide, doxorubicin, vincristine, prednisolone) regimen ${ }^{17}$. The use of RT as consolidation therapy in bulky disease or in patients with incomplete response was confirmed in retrospective studies ${ }^{18}$. Some randomized studies indicated that RT, if applied to the areas primarily affected by bulky disease, could significantly contribute to relapse-free survival and overall survival in patients with complete remission upon chemotherapeutic treatment ${ }^{19-23}$.

A study conducted in Mexico included 218 patients with stage IV diffuse large B-cell lymphoma (DLBCL). Of these, 155 (71\%) patients achieved complete remission on chemotherapy. Of the $155 \mathrm{pa}^{-}$ tients that achieved complete remission, $88(56 \%) \mathrm{pa}^{-}$ tients presented bulky disease $(>10 \mathrm{~cm})$. They were classified into the group being observed or in the involved-field RT (IFRT) group receiving 40-50 Gy. After 5 years, 43 (72\%) patients that received RT compared to 45 (35\%) patients in the non-irradiated group were alive and without signs of illness. Most relapses occurred in the primary area of the disease. Total survival was also better in the group of irradiated patients ( $81 \%$ vs. $55 \% ; \mathrm{p}<0.01)^{11}$. In a more recent study, 341 patients with aggressive DLBCL and nodal bulky $(>10 \mathrm{~cm})$ disease with pathologically proven complete remission after chemotherapy were randomized to the irradiated group (IFRT, $40 \mathrm{~Gy}$ ) or to the group being monitored. The 5-year event-free survival and overall survival were significantly better in the group of exposed patients (event-free survival $82 \%$ vs. 55\%; $\mathrm{p}<0.001$; overall survival $87 \%$ vs. $66 \% ; \mathrm{p}<0.01)$. RT was well tolerated and acute toxicity moderate ${ }^{19}$.

In a Milan study, 97 patients with stage III to IV DLBCL that were in complete remission after che- 
motherapy were either observed or received consolidation RT. At 5 years, patients with bulky disease $(<10$ $\mathrm{cm})$ that received RT had a significantly longer time to relapse and better overall survival $(\mathrm{p}<0.05)$ compared with patients that were not irradiated. A multivariate analysis showed that the use of RT was an independent favorable prognostic factor for relapse $(\mathrm{p}<0.001)$ and survival $(\mathrm{p}<0.05)^{12}$.

Non-Hodgkin's lymphoma is a systemic disease and all stages should be treated primarily with chemotherapy. RT to bulky or residual disease may improve the outcome of treatment. The potential benefit of RT in advanced-stage disease is not approved in prospective randomized studies but the above data provide an adequate basis to justify the combined-modality approach in selected cases.

\section{Radiation in the Abdominal Region}

Since the introduction of RT in the treatment, in the 1950s and during the 1960s, the treatment of abdominal presentation of the lymphoma was performed by irradiation of the entire abdomen. Patient tolerance to such treatment was poor. Patients had a significantly decreased blood cell count, diarrhea, nausea, feeling of increased tiredness, and loss of appetite ${ }^{24}$.

According to Surbone et al., 30\% of patients had an abdominal mass at diagnosis and $40 \%$ were left with a radiographically detectable residual mass at clinical complete remission. The likelihood of a residual mass was much higher in patients with bulky disease ${ }^{23}$. Results of several studies suggest that adding RT after chemotherapy treatment reduces the risk of local recurrence and improves survival without re-

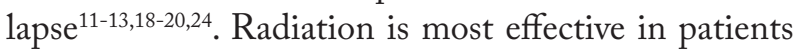
with poor prognostic factors (large tumor mass, extensive nodal involvement, and advanced stage of disease) and need adjuvant treatment to consolidate disease remission. It is possible to apply a more intensive chemotherapy scheme and bone marrow transplantation to achieve long lasting complete remission ${ }^{27}$. Although controversial, radiation in the abdominal area may be less toxic. Radiation can also be applied in refractory cases $^{28,29}$. Many studies confirm the viability and effectiveness of salvage radiation of tumor mass in the abdominal area ${ }^{30-34}$.

The first article describing abdominal irradiation of NHL patients appeared in 1976. Inverted Y field re- sulted in $29 \%$ of relapses. It was considered that the cause of such a high rate of local recurrence was the lack of coverage of mesenteric lymph nodes in the inverted $Y$ field of irradiation ${ }^{31}$. Later, Brihi et al. demonstrated that abdominal radiation was viable and effective in patients at a high risk of intra-abdominal relapse, for the treatment of residual disease after chemotherapy, and as palliative care that contributed to survival $^{29}$.

\section{Volume Definition and Side Effects of Infradiaphragmal Irradiation in Lymphoma Patients}

Radiation techniques for lymphomas have significantly changed over the last few decades. Partially, this is due to the reduction of the field boundaries and because of the introduction of combined treatment modalities and new drugs, which have superseded irradiation therapy as monotherapy.

Nowadays, large radiation fields that used to be applied are considered inadequate. Many of the historic concepts of dose and volume have been changed over the past few decades ${ }^{22,32,33}$. Irradiation therapy based on involved fields defined by anatomic landmarks and encompassing adjacent uninvolved lymph nodes is no longer appropriate for modern RT delivery.

Previously applied extended-field (EFRT) and involved-field (IFRT) RT techniques have been replaced with smaller volumes based solely on detectable nodal enrolment at presentation (involved site-ISRT/involved node-INRT) ${ }^{20,34-38}$. This is due to the general progress in radiation imaging and computer technology, including the introduction of three-dimensional conformal RT (3D-CRT), intensity-modulated RT (IMRT), image-guided RT (IGRT) and 4-dimensional RT (4D-RT). Advanced RT techniques allow the achievement of steep dose gradients in the radiation field along with spearing normal tissue. Initial diagnostic imaging (computed tomography (CT), magnetic resonance imaging (MRI) and positron emission tomography (PET)) facilitates the target volume definition, and significant radiation dose reductions at the organs at risk (kidneys, spinal cord, esophagus, liver and intestine). Reduction of the radiation fields has reduced toxicity while maintaining a high cure rate in combined modality treatment. The aim is to reduce normal tissue exposure, but not to 
compromise effective local control with such a reduced field size.

Volumes are delineated according to the International Commission on Radiation Units Measurement (ICRU) and ICRU supplements ${ }^{39-41}$, based on defining gross tumor volume (GTV) and clinical target volume (CTV). CTV has to be expanded to create planning target volume (PTV), which is used to define dose coverage. Implementation of other imaging methods such as PET/CT has enabled more precise target borders and volume determination. Thanks to CT planning and the possibilities to design the radiation plan in three dimensions, it is possible to define the volumes and doses to each volume of irradiation much more precisely. They allow the definition of planning volumes around the lymph node that have been affected, thus reducing the risk of toxicity and late side effects.

Pre-chemotherapy or preoperative GTV makes all areas affected by the disease before any intervention and should be labeled on the simulation CT because these volumes should be included in the CTV. CTV covers the original GTV (before any intervention), even if it extends beyond the original tissue and organs. Normal structures such as kidneys and muscles, which obviously were not affected, although displaced by GTV, should be excluded from CTV, depending on clinical judgment. PTV should be created by adding margin taking into account uncertainties in positioning the patients and adjusting the photons during irradiation delivery. This is the volume that has to be irradiated to make the CTV irradiated with the prescribed dose. PTV differs from institution to institution and needs to be calculated and determined in each case individually ${ }^{32,33}$.

\section{Organs at Risk}

The organs at risk (OAR) are critical organs or healthy organs near the irradiation field and they can cause significant morbidity if irradiated. This affects the treatment planning or determination of the radiation dose. Current knowledge of radiation toxicity is derived from conventional and newer 3D-CRT data. The Quantitative Analyses of Normal Tissue Effects in the Clinic (QUANTEC) project has produced data that are currently used to predict RT side effects and the plausibility of evaluated treatment plans ${ }^{42}$. Before being approved, all RT treatment plans have to be evaluated for the probability of organ-specific radiation toxicity. The clinician should consider dose-volume histograms and determine the likelihood of complications of healthy tissue, and then approve the radiation plan.

The number of organs at risk and the volume of normal tissue found in the radiation field may be significant. Due attention should be paid to short-term side effects and long-term morbidity, and accordingly target volume should be planned. Infradiaphragmal organs that limit the dose of radiation are spinal cord, kidneys, liver, and gastrointestinal system. Fortunately, doses that are used in lymphoma treatment are usually below the toxicity threshold for most organs. However, due to long survival rate and follow up of the patients, even small doses cannot be ignored.

There are dose limits for the organs at risk that have to be estimated but these doses are easy to meet within the lymphoma RT plans as radiation doses are significantly lower than in other solid tumors. However, dose limits and their compliance do not guarantee optimization of the plan in terms of side effects and complications of treatment. Long survival rate after combined modality treatment poses the risk of secondary malignancies or morbidities occurring in the radiation field.

\section{Liver}

The mean dose to the liver should be $\leq 30$ Gy because in $5 \%$ of patients it may cause radiation-induced liver disease (anicteric hepatomegaly, ascites, increased alkaline phospahtase). It typically occurs between 2 weeks and 3 months after RT ${ }^{43}$.

\section{Kidneys}

Kidneys are parallel organs, which means that one kidney can take over the role of the other one. So, radiation-induced renal dysfunction can be expressed in various ways, including decrease in creatinine clearance, biochemical changes and radiologic findings to renal failure. QUANTEC has estimated a $<5 \%$ risk of injury in 5 years when the mean kidney dose is limited to $<18 \mathrm{~Gy}^{44}$.

\section{Stomach and small bowel}

Nausea and vomiting are radiation-induced acute toxicity. They can occur within hours after RT to stom- 
ach or small-bowel. RT-induced injury to the stomach can range from self-limited mucosal inflammation causing dyspepsia to ulceration and bleeding. RT-induced small bowel mucositis can be expressed as cramping and diarrhea.

Late radiation-induced toxicity to the stomach includes dyspepsia and ulceration. A whole organ dose of $50 \mathrm{~Gy}$ has been associated with $2 \%$ to $6 \%$ risk of severe late toxicity.

The volume of the small bowel receiving relatively low doses of radiation plays a significant role in the rate of acute toxicity. When contouring individual bowel loops, the rate of grade $\geq 3$ acute toxicity is $<10 \%$ when V15 <120 cc. When the entire potential space within the peritoneal cavity is contoured, a V45 $<195$ cc results in $<10 \%$ acute toxicity ${ }^{45}$.

\section{Pancreas}

Radiation to para-aortic lymph nodes increases the risk of developing diabetes mellitus in 5-year Hodgkin's lymphoma survivors. Radiation dose $\geq 36 \mathrm{~Gy}$ is associated with 2 -fold increased risk of diabetes mellitus ${ }^{46}$.

\section{Spinal cord}

With conventional fractionation of 2 Gy per day including the full cord cross-section, a total RT dose of 50,60 and $70 \mathrm{~Gy}$ is associated with $0.2 \%, 6 \%$ and $50 \%$ rate of myelopathy, respectively. Re-irradiation data in animals and humans suggest partial repair of RT-induced subclinical damage becoming evident about 6 months post-RT and increasing over the next 2 years $^{47}$.

Total dose to spinal cord in Hodgkin's lymphoma and NHL patients is usually around $30 \mathrm{~Gy}$, so myelopathy is not an issue.

\section{Conclusion}

Radiotherapy is an effective and safe treatment option for patients with localized abdominal lymphoma. Modern RT for lymphomas is a highly individualized treatment. The newly defined concept of involved site RT that uses modern imaging and RT techniques should be incorporated in everyday practice to minimize the risk of long-term complications while achieving high local control and long-term survival. The optimal outcome for patients with lymphoma is only possible with collaborative multidisciplinary approach.

\section{References}

1. Shi Z, Das S, Okwan-Duodu D, Eshiasvili N, Flowers C, Chen $\mathrm{Z}$, et al. Patterns of failure in advanced stage diffuse large B cell lymphoma patients after complete response to $\mathrm{R}-\mathrm{CHOP}$ immunochemotherapy and the emerging role of consolidative radiation therapy. Int J Radiat Oncol Biol Phys. 2013;86: 569-77, https://doi.org/10.1016/j.ijrobp.2013.02.007

2. Zwick C, Held G, Ziepert N. The role of radiotherapy to bulky disease in elderly patients with aggressive B-cell lymphoma. Results from two prospective trials of the DSHNHL. Hematol Oncol. 2013;31:96:137, https://doi.org/10.1002/hon.2057

3. Dorth JA, Prosnitz LR, Broadwater G, Diehl LF, Beaven AW, Coleman RE, Kelsey CR. Impact of consolidation radiation therapy in stage III-IV diffuse large B-cell lymphoma with negative postchemotherapy radiologic imaging. Int J Radiat Oncol Biol Phys. 2012;84:762-7, https://doi.org/10.1016/j. ijrobp.2011.12.067

4. Dorth JA, Chino JP, Prosnitz LR, Diehl LF, Beaven AW, Coleman RE, et al. The impact of radiation therapy in patients with diffuse large B-cell lymphoma with positive postchemotherapy FDG-PET or gallium 67 scans. Ann Oncol. 2011;22:405-10, https://doi.org/10.1093/annonc/mdq389

5. Campbell BA, Connors JM, Gascoyne RD, Morris WJ, Pickles T, Sehn LH. Limited-stage diffuse large B-cell lymphoma treated with abbreviated systemic therapy and consolidation radiotherapy: involved-field versus involved-node radiotherapy. Cancer. 2012;118:4156-65, https://doi.org/10.1002/cncr.26687

6. Bush RS, Gospodarowicz M, Sturgeon J, Alison R. Radiation therapy of localized non-Hodgkin's lymphoma. Cancer Treat Rep. 1977;61(6):1129-36.

7. Berthold D, Ghielmini M. Treatment of malignant lymphoma. Swiss Med Wkly. 2004;134(33-34):472-80, https://doi.org/ 10.4414/smw.2004.10341

8. $\mathrm{Ng} \mathrm{AK}$, Mauch PM. Role of radiation therapy in localized aggressive lymphoma. J Clin Oncol. 2007;25:757-9, https:// doi.org/10.1200/JCO.2006.09.5562

9. Longo DL. Combined modality therapy for localized aggressive lymphoma: enough or too much? J Clin Oncol. 1989; 7:1179-81, https://doi.org/10.1200/JCO.1989.7.9.1179

10. Specht L. Does radiation have a role in advanced stage Hodgkin's or non-Hodgkin lymphoma? Curr Treat Options Oncol. 2016;17(1):4, https://doi.org/10.1007/s11864-015-0377-x

11. Aviles A, Delgado S, Nambo MJ, et al. Adjuvant radiotherapy to sites of previous bulky disease in patients stage IV diffuse large cell lymphoma. Int J Radiat Oncol Biol Phys. 1994;30: 799-803.

12. Ferreri AJ, Dell'Oro S, Reni M, Ceresoli GL, Cozzarini C Ponzoni $\mathrm{M}$, et al. Consolidation radiotherapy to bulky or semibulky lesions in the management of stage III-IV diffuse large B cell lymphomas. Oncology. 2000;58:219-26, https:// doi.org/10.1159/000012104

13. Schlembach PJ, Wilder RB, Tucker SL, Ha CS, Rodriguez MA, Hess MA, et al. Impact of involved field radiotherapy 
after CHOP-based chemotherapy on stage III-IV, intermediate grade and large-cell immunoblastic lymphomas. Int J Radiat Oncol Biol Phys. 2000;48:1107-10, https://doi.org/ 10.1016/S0360-3016(00)80466-6

14. Shipp MA, Klatt MM, Yeap B, Jochelson MS, Mauch PM, Rosenthal DS, et al. Patterns of relapse in large-cell lymphoma patients with bulk disease: implications for the use of adjuvant radiation therapy. J Clin Oncol. 1989;7:613-8, https://doi. org/10.1200/JCO.1989.7.5.613

15. Miller TP, Dahlberg S, Cassady JR, Adelstein DJ, Spier CM, Grogan TM, et al. Chemotherapy alone compared with chemotherapy plus radiotherapy for localized intermediate- and high-grade non-Hodgkin's lymphoma. N Engl J Med. 1998; 339:21-6, https://doi.org/10.1056/NEJM199807023390104

16. Glick JH, Kim K, Earle J, et al. An ECOG randomized phase III trial of CHOP vs. CHOP plus radiotherapy for intermediate grade early stage NHL. Proc Am Soc Clin Oncol. 1995; 14:391.

17. Fisher RI, Miller TP, O'Connor OA. Diffuse aggressive lymphoma. Hematology (Am Soc Hematol Educ Program). 2004; 1:221-36, https://doi.org/10.1182/asheducation-2004.1.221

18. Phan J, Mazloom A, Medeiros LJ, Zreik TG, Wogan C, Shihadeh F, et al. Benefit of consolidative radiation therapy in patients with diffuse large B-cell lymphoma Treat JCO. 2010; 28:4170-6, https://doi.org/10.1200/JCO.2009.27.3441

19. Aviles A, Fernandez R, Perez F, Nambo MJ, Neri N, Talavera A. Adjuvant radiotherapy in stage IV diffuse large cell lymphoma improves outcome. Leuk Lymphoma. 2004;45:1385-9,

20. National Comprehensive Cancer Network. NCCN Clinical Practice Guidelines in Oncology (NCCN Guidelines) NonHodgkin's Lymphoma. Version 3. 2018. http://www.nccn.org. Accessed 8 May 2018.

21. Delclos L, Braun EJ, Herrera JR, Sampiere VA, Van Roosenbeek E. Whole abdominal irradiation by cobalt-60 movingstrip technic. Radiology. 1963;81(4):632-41.

22. Elsayad K, Eich HT. Survival benefit by consolidating radiotherapy in patients with diffuse large B-cell lymphoma in early stages. Strahlenther Onkol. 2016;192:502-4 https://doi.org/ 10.1007/s00066-016-0992-x

23. Surbone A, Longo DL, DeVita VT Jr, Ihde DC, Duffey PL, Jaffe ES, et al. Residual abdominal masses in aggressive nonHodgkin's lymphoma after combination chemotherapy: significance and management. J Clin Oncol. 1988;6(12):1832-7, https://doi.org/10.1200/JCO.1988.6.12.1832

24. Horning SJ, Weller E, Kim K, Earle JD, O‘Connell MJ, Habermann TM, et al. Chemotherapy with or without radiotherapy in limited-stage diffuse aggressive non-Hodgkin's lymphoma: Eastern Cooperative Oncology Group Study 1484. J Clin Oncol. 2004;22:3032-8, https://doi.org/ 10.1200/JCO.2004.06.088

25. Fouillard L, Laporte JP, Labopin M, Lesage S, Isnard F, Douay L, et al. Autologous stem-cell transplantation for non Hodgkin's lymphoma: the role of graft purging and radiotherapy. J Clin Oncol. 1998;8:2803-16,
https://doi.org/10.1200/JCO.1998.16.8.2803

26. Haas RL, Poortmans P, de Jong D, Aleman BM, Dewit LG, Verheij $\mathrm{M}$, et al. High response rates and lasting remissions after low-dose involved field radiotherapy in indolent lymphomas. J Clin Oncol. 2003;21:2474-80, https://doi.org/ 10.1200/ JCO.2003.09.542

27. Haas RL, Girinsky T. HOVON 47/EORTC 20013: chlorambucil os $2 \times 2$ Gy involved field radiotherapy in stage III/IV previously untreated follicular lymphoma patients. Ann Hematol. 2003;82:458-62, https://doi.org/10.1007/s00277-003-0655-8

28. Akoum R, Brihi E, Saade M, Hanna T, Chahine G. Salvage abdominal irradiation for refractory non-Hodgkin's lymphoma. J Can Res Ther. 2007;3:143-9, https://doi.org/10.4103/09731482.37406

29. Brihi E, Akoum R, Saade M, Chanine G. Abdominal irradiation after chemotherapy in non-Hodgkin's lymphoma: review of 32 patients. Mol Immunol. 2003;39:1121-8.

30. Valicenti RK, Wasserman TH, Monyak DJ, Kucik NA. NonHodgkin's lymphoma: whole-abdomen irradiation as an adjuvant to chemotherapy. Radiology. 1994;192:571-6, https: //doi.org/10.1148/radiology.192.2.8029434

31. Goffinet R, Glatstein E, Fuks Z, Kaplan HS. Abdominal irradiation in non-Hodgkin's lymphoma. Cancer. 1976;37:2797-806.

32. Yahalom J, Illridge T, Specht L, Hppe RT, Li XY, Tsang R, et al. Modern radiation therapy for extranodal lymphomas: field and dose guidelines from the International Lymphoma Radiation Oncology Group. Int J Radiat Oncol Biol Phys. 2015; 92:11-31, https://doi.org/10.1016/j.ijrobp.2015.01.009

33. Illidge T, Specht L, Yahalom J, Aleman B, Berthelsen AK, Constine $\mathrm{K}$, et al. Modern radiation therapy for nodal nonHodgkin lymphoma - target definition and dose guidelines from the International Lymphoma Radiation Oncology Group. IJROBP. 2014;89:49-58, https://doi.org/10.1016/j. ijrobp.2014.01.006

34. Yu JI, Nam H, Ahn YC, Kim WS, Park K, Kim SJ. Involved lesion radiation therapy after chemotherapy in limited stage head and neck diffuse large B cell lymphoma. Int J Radiat Oncol Biol Phys. 2010;78:507-12, https://doi.org/10.1016/j. ijrobp.2009.07.1706

35. Verhappen MH, Poortmans PMP, Raaijmakers E, Raemaekers JM. Reduction of the treated volume to involved node radiation therapy as part of combined modality treatment for early stage aggressive non-Hodgkin's lymphoma. Radiother Oncol. 2013;109:133-9,https://doi.org/10.1016/j.radonc.2013.07.013

36. Girinsky T, van der Maazen R, Specht L, Aleman B, Poortmans $\mathrm{P}$, Lievens $\mathrm{Y}$, et al. Involved-node radiotherapy (INRT) in patients with early Hodgkin lymphoma: concepts and guidelines. Radiother Oncol. 2006;79(3):270-7, https://doi. org/10.1016/j.radonc.2006.05.015

37. Hoppe BS, Moskowitz CH, Filippa DA, Moskowitz CS, Kewalramani $\mathrm{T}$, Zelenetz $\mathrm{AD}$, et al. Involved-field radiotherapy before high-dose therapy and autologous stem-cell rescue in diffuse large-cell lymphoma: long-term disease control and toxic- 
ity. J Clin Oncol. 2008;26:1858-64, https://doi.org/10.1200/ JCO.2007.15.4773

38. Girinsky T, Specht L, Ghalibafian M, Edeline V, Bonniaud G, Van Der Maazen R, et al. The conundrum of Hodgkin lymphoma nodes: to be or not to be included in the involved node radiation fields. The EORTC-GELA Lymphoma Group Guidelines. Radiother Oncol. 2008;88 (2):202-10, https://doi. org/10.1016/j.radonc.2008.05.012

39. DeLuca P, Jones D, Gahbauer R, et al. Prescribing, recording, and reporting photon-beam intensity-modulated radiation therapy (IMRT) (report 83). J ICRU 2010;10:1-106, https:// doi.org/10.1093/jicru/10.1.Report83

40. ICRU. Prescribing, recording and reporting photon-beam therapy (report 50). J ICRU. 1993.

41. ICRU. Prescribing, recording and reporting photon-beam therapy (report 62). Suppl to ICRU Report 50. J ICRU. 1999;ix-52.

42. Bentzen SM, Constine LS, Deasy JO, et al. Quantitative Analyses of Normal Tissue Effects in the Clinic (QUANTEC): an introduction to the scientific issuees, IJROBP. 2010;76:3-9, https://doi.org/10.1016/j.ijrobp.2009.09.040

43. Pan CC, Kavanagh BD, Dawson LA, et al. Radiation-associated liver injury. IJROBP. 2010;76:94-100, https://doi.org/ 10.1016/j.ijrobp.2009.06.092

44. Dawson LA, Kavanagh BD, Paulino AC, et al. Radiation-associated kidney injury. IJROBP. 2010;76:108-15, https://doi. org/10.1016/j.ijrobp.2009.02.089

45. Kavanagh BD, Pan CC Dawson LA, et al. Radiation dosevolume effects in the stomach and small bowel. IJROBP. 2010;76:101-7, https://doi.org/10.1016/j.ijrobp.2009.05.071

46. van Nimwegen FA, Shcaapveld M, Janus CP, et al. Risk of diabetes mellitus in long-term survivors of Hodgkin lymphoma. J Clin Oncol. 2014;32(29): 3257-63, https://doi.org/ 10.1200/JCO.2013.54.4379

47. Kirkpatrik JP, van der Kogel A, Schultheiss TE. Radiation dose-volume effects in the spinal cord. IJROBP. 2010;76:42-9, https://doi.org/10.1016/j.ijrobp.2009.04.095

Sažetak

\section{RADIOTERAPIJA INFRADIJAFRAGMALNIH POLJA U BOLESNIKA S LIMFOMIMA: VOLUMENI I NUSPOJAVE}

\section{Galunić Bilić i F. Šantek}

Limfomi su vrlo radiosenzitivni pa je radioterapija (RT) bila prva metoda liječenja koja je omogućavala izliječenje. Ona je i dalje najučinkovitiji pojedinačni modalitet liječenja limfoma. Međutim, RT je lokalna terapija i kao jedini oblik liječenja dolazi u obzir ako je moguće sve tumorsko tkivo uključiti u volumen koji će se zračiti. Stoga se danas RT primjenjuje kao primarni modalitet liječenja samo u ranom stadiju nodularne limfocitne predominacije Hodgkinova limfoma i indolentnih ne-Hodgkinovih limfoma. U većine bolesnika RT je dio kombiniranog modaliteta liječenja kao konsolidacija nakon kemoterapijskog liječenja. Kod bolesnika u uznapredovalim stadijima bolesti RT se može primijeniti kao dio planiranog liječenja kada se RT aplicira na mjesta visokog rizika za recidiv te u slučajevima insuficijentnog odgovora na kemoterapiju. U protekla dva desetljeća tehnike zračenja su se promijenile te omogućavaju značajnije očuvanje rizičnih organa i smanjenje nuspojava. Iako učinkovita, RT je zanemaren modalitet liječenja zbog dostupnosti novih lijekova te zbog straha od nuspojava nakon zračenja. Zračenje je učinkovito u svim stadijima i oblicima limfoma. Dostupni podaci o učinkovitosti i nuspojavama RT odnose se na supradijafragmalna polja, zbog toga su potrebna istraživanja o najboljem RT pristupu liječenju bolesnika s infradijafragmalnom prezentacijom limfoma.

Ključne riječi: Limfom, ne-Hodgkinov; Radijacijska tolerancija; Radioterapija 